\title{
Inhibitive Action of Argan Press Cake Extract on the Corrosion of Steel in Acidic Media
}

\author{
L. Afia, ${ }^{a}$ R. Salghi, ${ }^{a}{ }^{*}$ A. Zarrouk, ${ }^{b}$ H. Zarrok, ${ }^{c}$ O. Benali, ${ }^{d}$ B. Hammouti, ${ }^{e}$ \\ S.S. Al-Deyab, ${ }^{f}$ A. Chakir ${ }^{g}$ and L. Bazzi ${ }^{h}$ \\ ${ }^{a}$ Ecole Nationale des Sciences Appliquées, Equipe Génie de l'Environnement et de Biotechnologie, B.P 1136, 80000 \\ Agadir, Morocco. \\ ${ }^{b}$ LCAE-URAC18, Faculté des Sciences, Université Mohammed Premier, B.P. 4808, 60046 Oujda, Morocco \\ ${ }^{c}$ Laboratoire des procèdes de séparation, Faculté des Sciences, Kénitra, Morocco \\ ${ }^{d}$ Département de biologie, Université de Tahar Moulay Sä̈da, Algérie. \\ ${ }^{e}$ LCAE-URAC18, Faculté des Sciences, Université Mohammed Premier, B.P. 4808, 60046 Oujda, Morocco \\ ${ }^{f}$ Department of Chemistry, College of Science, King Saud University, B.O. 2455, Riaydh 11451, Saudi Arabia \\ ${ }^{g}$ GSMA UMR CNRS 6089, Laboratoire de Chimie-Physique, Faculté des Sciences, Université de Reims, UMR 6089, \\ BP 1039, France. \\ ${ }^{h}$ Laboratoire Matériaux \& Environnement, Faculté des Sciences, Université Ibn Zohr, BP 8106, Agadir, Morocco.
}

Received 13 May 2012; accepted 31 August 2012

\begin{abstract}
The inhibitive action of the Argan press cake extract (ACE) against corrosion of C38 steel in a $1 \mathrm{M} \mathrm{HCl}$ solution was investigated using potentiodynamic polarization curves, electrochemical impedance spectroscopy (EIS) and weight loss measurements. The inhibition efficiency increases with increasing extract concentration and decreases with temperature. The kinetic parameters (activation energy, pre-exponential factor, enthalpy of activation and entropy of activation) were calculated and discussed. The Argan press cake extract acted as a mixed-type inhibitor with predominant cathodic effectiveness. The Nyquist plots showed that on increasing ACE concentration, increases charge transfer resistance and decreases double layer capacitance. The adsorption of components of the the Argan press cake extract (ACE) on the surface of the C38 steel follows the Langmuir adsorption isotherm. E (\%) values obtained from various methods used are in good agreement.
\end{abstract}

Keywords: Argan press cake extract, inhibition, steel, weight loss, potentiodynamic polarization.

\section{Introduction}

Steel is widely used in most industries because of its low cost and availability for the manufacture of reaction vessels such as cooling tower reservoirs, pipelines, etc. [1]. Large numbers of organic compounds were studied and are

\footnotetext{
*Corresponding author. E-mail: r_salghi@yahoo.fr
} 
being studied to investigate their corrosion inhibition potential. All these studies reveal that organic compounds, especially those with $\mathrm{N}, \mathrm{S}$ and $\mathrm{O}$, showed significant inhibition efficiency [2-12]. But, unfortunately most of these compounds are not only expensive but also toxic to living beings. It is needless to point out the importance of cheap, safe inhibitors of corrosion. Plant extracts are environmentally friendly, bio-degradable, non-toxic, easily available and of potentially low cost. Most of the naturally occurring substances are safe and can be extracted by simple procedures. Recent literature is full of researches which test different extracts for corrosion inhibition applications. The examples are numerous such as Argan Hulls [13], Thymus capitatus [14-15], Fenugreek [16], Artemisia [17], Hibiscus sabdariffa [18], Oxandra asbeckii [19], Citrus paradise [20] and Anacyclus pyrethrum L. [21].

This study examines the action of Argan press cake extract as corrosion inhibitor of steel in acid medium with various concentrations. The kinetics of corrosion of steel in acid medium has been identified by electrochemical and weight loss measurements.

\section{Materials and methods \\ Weight loss measurements}

Coupons were cut into $(20 \times 20 \times 0.8) \mathrm{mm}$ dimensions having composition $(0.179 \% \mathrm{C}, 0.165 \% \mathrm{Si}, 0.439 \% \mathrm{Mn}, 0.203 \% \mathrm{Cu}, 0.034 \% \mathrm{~S}$ and Fe balance) and have been used for weight loss measurements. Prior to all measurements, the exposed area was mechanically abraded with 180, 320, 800, 1200 grades of emery papers. The specimens were washed thoroughly with bidistilled water, degreased and dried with ethanol. Gravimetric measurements were carried out in a double walled glass cell equipped with a thermostated cooling condenser. The solution volume is $80 \mathrm{~cm}^{3}$. The immersion time for the weight loss is $6 \mathrm{~h}$ at $298 \mathrm{~K}$.

\section{Electrochemical tests}

The electrochemical study was carried out using a potentiostat PGZ100 piloted by Voltamaster software. This potentiostat is connected to a cell with three electrode thermostats with double wall (Tacussel Standard CEC/TH). A saturated calomel electrode (SCE) and a platinum electrode were used as reference and auxiliary electrodes, respectively. The material used for constructing the working electrode was the same used for gravimetric measurements. The surface area exposed to the electrolyte is $0.056 \mathrm{~cm}^{2}$.

Potentiodynamic polarization curves were plotted at a polarization scan rate of $0.5 \mathrm{mV} / \mathrm{s}$. Before all experiments, the potential was stabilized at free potential during $30 \mathrm{~min}$. The polarization curves have been obtained from $-800 \mathrm{mV}$ to $-400 \mathrm{mV}$ at $298 \mathrm{~K}$. The solution test is used after being de-aerated by bubbling nitrogen. Gas bubbling is maintained prior and through the experiments. In order to investigate the effects of temperature and immersion time on the 
inhibitor performance, some tests were carried out in a temperature range 298$328 \mathrm{~K}$.

The electrochemical impedance spectroscopy (EIS) measurements were carried out with the electrochemical system (Tacussel), which included a digital potentiostat model Voltalab PGZ100 computer at Ecorr after immersion in solution without bubbling. After the determination of steady-state current at a corrosion potential, the signals of sine wave voltage $(10 \mathrm{mV})$ peak to peak, at frequencies between $100 \mathrm{kHz}$ and $10 \mathrm{mHz}$ are superimposed on the rest potential. Computer programs automatically controlled the measurements performed at rest potentials after $30 \mathrm{~min}$ of exposure at $298 \mathrm{~K}$. The impedance diagrams are given in the Nyquist representation. Experiments are repeated three times to ensure the reproducibility.

\section{Solutions preparation}

A sample of Argan press cake was collected from the area of Biougra (located at Chtouka Ait Baha). Dried and pulping fruits were crushed. Stock solution of the Argan press cake extract was prepared by stirring cold weighed for $24 \mathrm{~h}$ in $1 \mathrm{M} \mathrm{HCl}$ solution (a $1 \mathrm{M} \mathrm{HCl}$ solution was prepared by dilution of analytical grade $37 \% \mathrm{HCl}$ with double distilled water). The resulting solution was filtered. This extract was used to study the corrosion inhibition properties and to prepare the required concentrations. The test solutions are freshly prepared before each experiment.

\section{Results and discussion \\ Polarization curves}

Evaluation of the inhibition efficiencies can be performed through electrochemical experiments which consist of the determination of current density/potential curves. Fig. 1 shows the dc polarization curves of C38 steel in 1 $M$ hydrochloric acid without and with Argan press cake extract (ACE) concentrations at $298 \mathrm{~K}$. Electrochemical kinetic parameters (corrosion potential $\left(E_{\text {corr }}\right)$, corrosion current density $\left(I_{\text {corr }}\right)$ cathodic and anodic Tafel slopes $\left(\mathrm{b}_{\mathrm{c}}\right.$ and $b_{a}$ ), determined from these experiments by extrapolation method, are reported in Table 1. The inhibition efficiency (EI \%) is given in equation 1.

$$
\mathrm{EI} \%=\frac{\mathrm{I}_{\text {corr }}-\mathrm{I}_{\text {corr }}^{\prime}}{\mathrm{I}_{\text {corr }}} \times 100
$$

where $I_{\text {corr }}$ and $I_{\text {corr }}^{\prime}$ are corrosion current densities in absence and presence of Argan press cake extract.

It is clear from the electrochemical polarisation results that the addition of inhibitor causes a decrease of the current density. The values $\mathrm{I}_{\text {corr }}$ of C38 steel in the inhibited solution are smaller than those for the inhibitor free solution (Table 1). The parallel cathodic Tafel plots obtained in Fig. 1 indicate that the hydrogen evolution is activation-controlled and the reduction mechanism is not affected by the presence of the inhibitor. The anodic branches are slightly affected in the presence of this inhibitor. However, a shift of corrosion potential $\left(\mathrm{E}_{\mathrm{corr}}\right)$ towards 
cathodic side i.e -567 to $-718 \mathrm{mV}$ was established. The classification of a compound as an anodic or cathodic inhibitor is feasible when the corrosion potential displacement is at least $85 \mathrm{mV}$ in relation to that one measured for the blank solution [22]. In our case the displacement is greater than $120 \mathrm{mV}$, so we can classify our inhibitor as mixed inhibitor with predominant cathodic effectiveness. On the other hand, for anodic polarization, it can be seen from Fig. 1 that, in the presence of ACE at different concentrations, two linear portions were observed. When the anodic potentials increase, the anodic current increases at a slope of $b_{a 1}$ in the low polarization potential region. After passing a certain potential $E_{u}$, the anodic current increases rapidly and dissolves at a slope of $b_{a 2}$ in the high polarization region. The rapid increase of anodic current after $\mathrm{E}_{\mathrm{u}}$ may be due to desorption of ACE molecules adsorbed on the electrode. This means that the inhibition mode of ACE extract depends on the electrode potential. In this case, the observed inhibition phenomenon is generally described as corrosion inhibition of the interface associated with the formation of a bidimensional layer of adsorbed inhibitor species at the electrode surface [23-24 ]. Note that the potential $\mathrm{E}_{\mathrm{u}}$ is also denoted $\mathrm{E}_{1}$ in Bartos and Hackerman's paper [25].

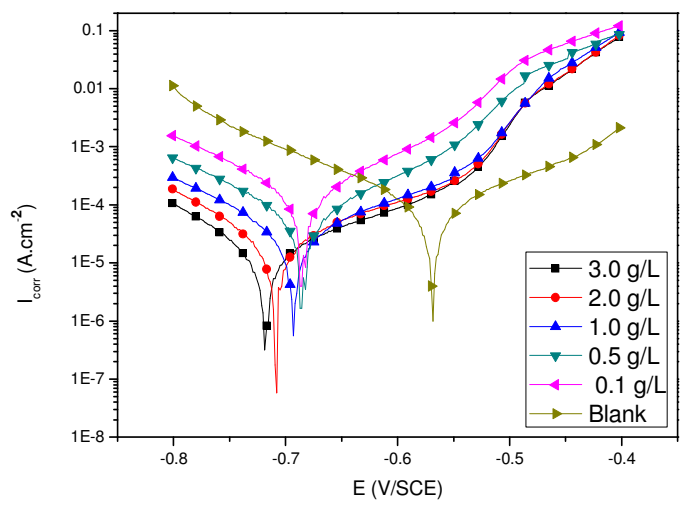

Figure 1. Potentiodynamic polarization curves of steel in $1 \mathrm{M} \mathrm{HCl}$ in the presence of different concentrations of ACE extract.

Table 1. Electrochemical parameters of steel at various concentrations of ACE extract in $1 \mathrm{M} \mathrm{HCl}$ and corresponding inhibition efficiency.

\begin{tabular}{cccccc}
\hline Conc. $(\mathrm{g} / \mathrm{L})$ & $\mathrm{E}_{\text {corr }}(\mathrm{mV} / \mathrm{SCE})$ & $\mathrm{I}_{\text {corr }}\left(\mu \mathrm{A} / \mathrm{cm}^{2}\right)$ & $-\mathrm{b}_{\mathrm{c}}(\mathrm{mV} / \mathrm{dec})$ & $\mathrm{b}_{\mathrm{a}}(\mathrm{mV} / \mathrm{dec})$ & $\mathrm{E}_{\mathrm{I}}(\%)$ \\
\hline Blank & -567 & 94 & 99 & 108 & --- \\
\hline $0.1 \mathrm{~g} / \mathrm{L}$ & -686 & 86 & 80 & 84 & 8.5 \\
$0.5 \mathrm{~g} / \mathrm{L}$ & -680 & 60 & 91 & 99 & 36.2 \\
$1.0 \mathrm{~g} / \mathrm{L}$ & -694 & 29 & 82 & 117 & 69.1 \\
$2.0 \mathrm{~g} / \mathrm{L}$ & -709 & 18 & 79 & 89 & 80.9 \\
$3.0 \mathrm{~g} / \mathrm{L}$ & -718 & 11 & 69 & 111 & 88.3 \\
\hline
\end{tabular}

\section{Electrochemical impedance spectroscopy measurements}

Fig. 2 shows the Nyquist plots for $\mathrm{C} 38$ steel in $1 \mathrm{M} \mathrm{HCl}$ solution in the absence and presence of different concentrations of the ACE extract at 298K. The 
obtained Nyquist impedance diagrams in most cases do not show perfect semicircles, generally attributed to the frequency dispersion as a result of roughness and inhomogenates of the electrode surface. The data reveal that each impedance diagram consists of a large capacitive loop with low frequencies dispersion (inductive arc).

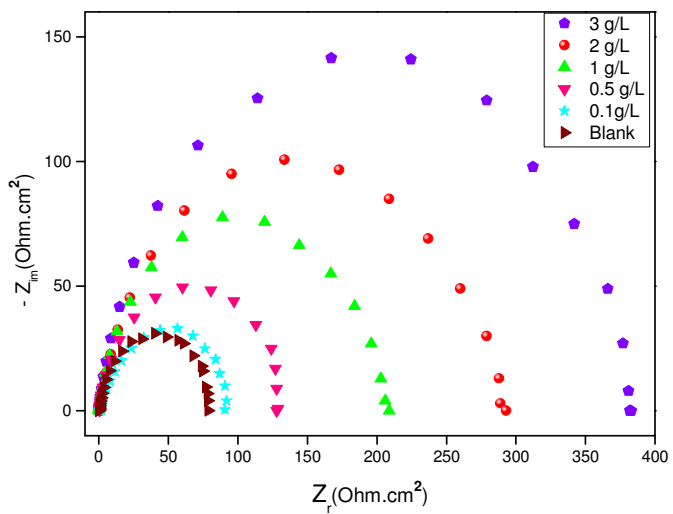

Figure 2. Nyquist diagrams for steel electrode with and without Argan press cake extract after $30 \mathrm{~min}$ of immersion.

This inductive arc is generally attributed to anodic adsorbed intermediates controlling the anodic process [26-27].

The circuit consists of a constant phase element $(\mathrm{CPE}) \mathrm{Q}$, in parallel with a resistor $\mathrm{R}_{\mathrm{t}}$. The use of CPE-type impedance has been extensively described in $[21,28-29]:$

$$
\mathrm{Z}_{\mathrm{CPE}}=\left[\mathrm{Q}(\mathrm{jw})^{\mathrm{n}}\right]^{-1}
$$

The above equation provides information about the degree of non-ideality in capacitance behaviour. Its value makes it possible to differentiate between the behavior of an ideal capacitor $(n=1)$ and of a CPE $(n<1)$. Considering that a CPE may be considered as a parallel combination of a pure capacitor and a resistor that is inversely proportional to the angular frequency, the value of capacitance, $\mathrm{C}_{\mathrm{dl}}$, can thus be calculated for a parallel circuit composed of a CPE (Q) and a resistor $\left(\mathrm{R}_{\mathrm{t}}\right)$, according to the following formula [30, 31]:

$$
\mathrm{Q}=\left(\mathrm{C}_{\mathrm{dl}} \mathrm{R}_{\mathrm{t}}\right)^{\mathrm{n}} / \mathrm{R}_{\mathrm{t}}
$$

The impedance spectra were analyzed by using the circuit in Fig. 3, and the double layer capacitance $\left(\mathrm{C}_{\mathrm{dl}}\right)$ was calculated in terms of Eq. 3. Values of elements of the circuit corresponding to different corrosion systems, including values of $\mathrm{C}_{\mathrm{dl}}$, are listed in Table 2 .

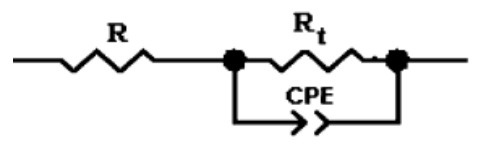

Figure 3. The equivalent circuit of the impedance spectra obtained for ACE extract. 
Table 2. Impedance parameters for the corrosion of mild steel in $1 \mathrm{M} \mathrm{HCl}$ containing different concentrations of ACE.

\begin{tabular}{cccccc}
\hline Conc. $(\mathrm{g} / \mathrm{L})$ & $\mathrm{R}_{\mathrm{t}}\left(\Omega . \mathrm{cm}^{2}\right)$ & $\mathrm{Q}\left(\mathrm{S}^{\mathrm{n}} \cdot \Omega^{-1} \cdot \mathrm{cm}^{-2}\right)$ & $\mathrm{C}_{\mathrm{dl}}\left(\mu \mathrm{F} . \mathrm{cm}^{-2}\right)$ & $\mathrm{n}$ & $\mathrm{E}_{\mathrm{Rt}}(\%)$ \\
\hline Blank & 74 & $3.74 \times 10^{-5}$ & 37.4 & 0.90 & --- \\
\hline 0.1 & 88 & $3.42 \times 10^{-5}$ & 34.2 & 0.82 & 15.9 \\
0.5 & 120 & $2.76 \times 10^{-5}$ & 27.6 & 0.91 & 38.3 \\
1 & 207 & $1.94 \times 10^{-5}$ & 19.4 & 0.95 & 64.3 \\
2 & 280 & $1.32 \times 10^{-5}$ & 13.2 & 0.87 & 73.6 \\
3 & 360 & $1.03 \times 10^{-5}$ & 10.3 & 0.89 & 79.4 \\
\hline
\end{tabular}

The inhibition efficiency obtained from the impedance measurements is defined by the following relation:

$$
\mathrm{P} \%=\frac{\mathrm{R}_{\mathrm{t}}^{\prime}-\mathrm{R}_{\mathrm{t}}}{\mathrm{R}_{\mathrm{t}}^{\prime}} \times 100
$$

where $R_{t}^{\prime}$ and $R_{t}$ are the charge transfer resistance in the absence and presence of different concentrations of the inhibitor, respectively.

The examination of the results of Table 2 enables us to deduce the following points:

- The $\mathrm{R}_{\mathrm{t}}$ values increased with the increasing concentration of the inhibitor, indicating that more inhibitor molecules adsorb on the metal surface at higher concentration and form a protective film on the metal-solution interface [3233].

- $\mathrm{C}_{\mathrm{dl}}$ value decreased with increasing inhibitor concentration. Decrease of $\mathrm{C}_{\mathrm{dl}}$ may be caused by a reduction in local dielectric constant and/or by an increase in the thickness of the electrical double layer. These results indicate that the inhibitor acts by adsorption on the metal/solution interface [34, 35]. These observations suggest that ACE inhibitor functions by adsorption on the metal surface, thereby causing a decrease in the $C_{d l}$ values and an increase in the $R_{t}$ values.

- The value of $\mathrm{n}$ grows as well (0.82-0.95.), when compared to that obtained in pure $\mathrm{HCl}$. This can be attributed to a certain decrease of the initial surface inhomogeneity resulting from the inhibitor's adsorption on the most active centers [29].

- The inhibiting effectiveness increases with the concentration of the inhibitor to reach a maximum value of $79.6 \%$ at $3 \mathrm{~g} / \mathrm{L}$.

\section{Gravimetric measurements (effect of concentration)}

Weight loss data of $\mathrm{C} 38$ steel in $1 \mathrm{M} \mathrm{HCl}$ in the absence and presence of various concentrations of inhibitor were obtained and are given in Table 3. From the weight loss results, the inhibition efficiency $\left(\mathrm{E}_{\mathrm{w}} \%\right)$ of the inhibitor and degree of surface coverage $(\theta)$ were calculated using equations 5 and 6 [36]; 


$$
\begin{aligned}
& \mathrm{E}_{\mathrm{W}} \%=1-\frac{\mathrm{W}_{\text {corr }}}{\mathrm{W}_{\text {corr }}^{0}} \times 100 \\
& \theta=1-\frac{\mathrm{W}_{\text {corr }}}{\mathrm{W}_{\text {corr }}^{0}}
\end{aligned}
$$

where $\mathrm{W}_{\text {corr }}$ and $\mathrm{W}_{\text {corr }}^{0}$ are the weight losses for $\mathrm{C} 38$ steel in the presence and absence of the extract in $\mathrm{HCl}$ solution, and $\theta$ is the degree of surface coverage of the inhibitor.

Table 3. Effect of Argan press cake concentration on corrosion data of steel in $1 \mathrm{M}$ $\mathrm{HCl}$.

\begin{tabular}{cccc}
\hline Conc. $(\mathrm{g} / \mathrm{L})$ & $\mathrm{W}_{\text {corr }}\left(\mathrm{mg} / \mathrm{cm}^{2} . \mathrm{h}\right)$ & $\mathrm{E}_{\mathrm{w}}(\%)$ & $\theta$ \\
\hline Blank & 1.8614 & --- & --- \\
\hline 0.1 & 1.7006 & 08.6 & 0.086 \\
0.5 & 1.1005 & 40.9 & 0.409 \\
1.0 & 0.5413 & 68.2 & 0.682 \\
2.0 & 0.2006 & 81.8 & 0.818 \\
3.0 & 0.0764 & 85.9 & 0.859
\end{tabular}

From Table 3 it has also been observed that the inhibition efficiency for this compound increases with the increase in concentration. Maximum $\mathrm{E}_{\mathrm{w}}(\%)$ for this compound was achieved at $3 \mathrm{~g} / \mathrm{L}$ and a further increase in concentration did not cause any appreciable change in the performance of the inhibitor (gravimetric measurement). The corrosion inhibition can be attributed to the adsorption of this compound at the $\mathrm{C} 38$ steel / acid solution interface. The corrosion rate decreases with the concentration of the inhibitor and in turn the inhibition efficiency evaluated from weight loss measurements increases to attain $85.9 \%$ for $3 \mathrm{~g} \mathrm{~L}^{-1}$.

\section{Adsorption isotherm and thermodynamic activation parameters}

It is well established that the first step in corrosion inhibition of metals and alloys is the adsorption of organic inhibitor molecules at the metal/solution interface and that the adsorption depends on the molecule's chemical composition, the temperature, and the electrochemical potential at the metal/solution interface. In fact, the solvent water molecules could also adsorb at the metal/solution interface. So, the adsorption of organic inhibitor molecules from the aqueous solution can be regarded as a quasi-substitution process between the organic compounds in the aqueous phase $\left[\mathrm{Org}_{(\mathrm{sol})}\right]$ and water molecules at the electrode surface $\left[\mathrm{H}_{2} \mathrm{O}_{(\mathrm{ads})}\right][37]$.

$$
\mathrm{Org}_{(\mathrm{sol})}+\mathrm{nH}_{2} \mathrm{O}_{(\mathrm{ads})} \Leftrightarrow \mathrm{Org}_{(\mathrm{ads})}+\mathrm{nH}_{2} \mathrm{O}_{(\mathrm{sol})}
$$

where $\operatorname{Org}_{(\mathrm{sol})}$ and $\operatorname{Org}_{(\mathrm{ads})}$ are the organic species dissolved in the aqueous solution and adsorbed onto the metallic surface, respectively, $\mathrm{H}_{2} \mathrm{O}_{\text {(ads) }}$ is the water molecule adsorbed on the metallic surface, and $\mathrm{n}$ is the size ratio representing the number of water molecules replaced by one organic adsorbate. Basic information 
on the adsorption of the inhibitors on the metal surface can be provided by adsorption isotherm. In order to obtain the isotherm, the fractional surface coverage values $(\theta)$ as a function of the inhibitor concentration must be obtained. The values of $\theta$ can be easily determined from weight loss measurements by the ratio $\mathrm{E}_{\mathrm{W}} \%$ / 100, where $\mathrm{E}_{\mathrm{W}} \%$ is the inhibition efficiency obtained by weight loss method. So, it is necessary to determine empirically which isotherm fits best to the adsorption of the inhibitor on the steel surface. Several adsorption isotherms (viz., Frumkin, Langmuir, Temkin, Freundlich) were tested, and the Langmuir adsorption isotherm was found to provide the best description of the adsorption behaviour of this inhibitor. The Langmuir isotherm is given by the following equation [38]:

$$
\frac{\mathrm{C}}{\theta}=\frac{1}{\mathrm{~K}}+\mathrm{C}
$$

where $\mathrm{C}$ is the concentration of inhibitor, $\mathrm{K}_{\mathrm{ads}}$ is the equilibrium constant of the adsorption process, and $\theta$ is the surface coverage.

Plot $\mathrm{C} / \theta$ versus $\mathrm{C}$ yields a straight line (Fig. 4) with regression coefficient, $\mathrm{R}^{2}$, almost equal to 1 . This suggests that the extract in the present study obeyed the Langmuir isotherm and that the interaction between the adsorbed molecules is negligible.

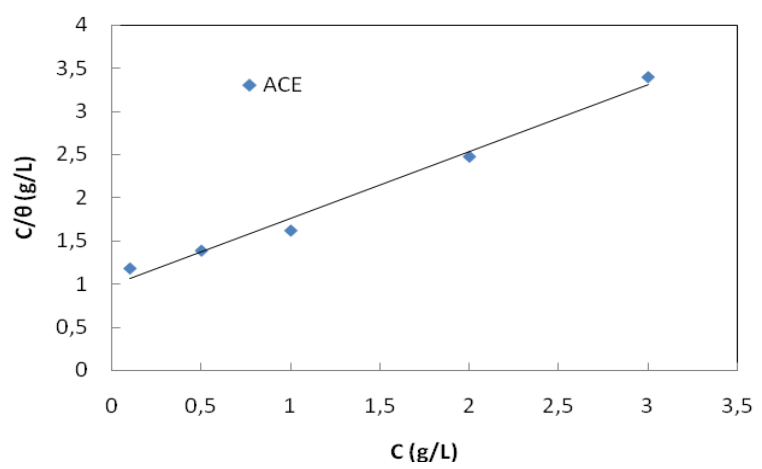

Figure 4. Plots of Langmuir adsorption isotherm of ACE on the steel surface at $298 \mathrm{~K}$.

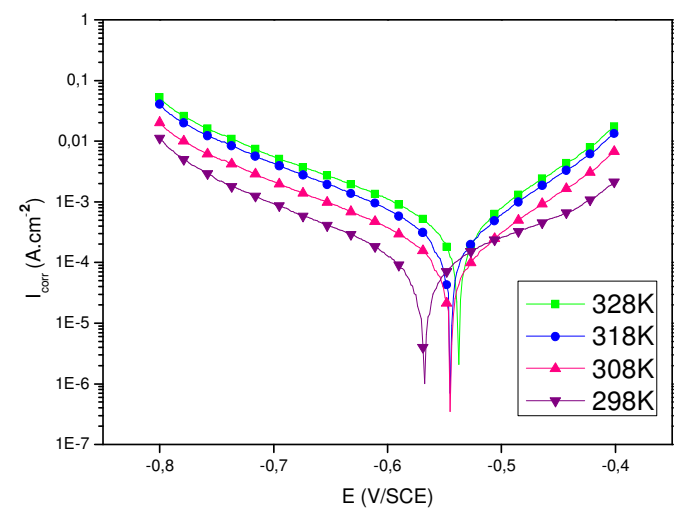

Figure 5. Effect of temperature on the cathodic and anodic responses for $\mathrm{C} 38$ steel in $1 \mathrm{M} \mathrm{HCl}$. 


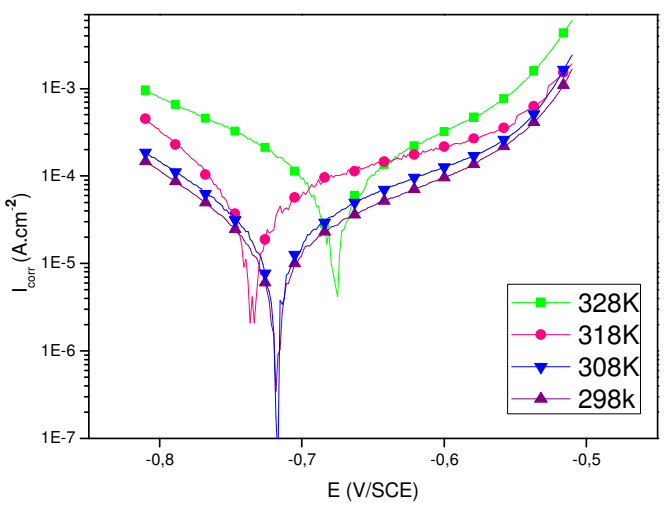

Figure 6. Effect of temperature on the cathodic and anodic responses for $\mathrm{C} 38$ steel in $1 \mathrm{M} \mathrm{HCl}+3 \mathrm{~g} / \mathrm{L}$ of $\mathrm{ACE}$.

Generally, the corrosion rate of steel in acidic solution increases with rising the temperature. This is due to the decrease of hydrogen evolution overpotential [39]. In order to understand more about the performance of Argan press cake extract (ACE) with the nature of adsorption and activation processes, the effect of temperature is studied. For this purpose, the potentiodynamic polarizations are being employed with the range of temperature 298, 308, 318 and $328 \mathrm{~K}$ for 30 min of immersion, in the absence and presence of $3 \mathrm{~g} / \mathrm{L}$ of the inhibitor (Figs. 5 and 6). Corresponding data are given in Table 4.

Table 4. Effect of temperature on the steel in free acid and at $3 \mathrm{~g} / \mathrm{L}$ of ACE.

\begin{tabular}{|c|c|c|c|c|c|c|}
\hline & $\mathrm{T}(\mathrm{K})$ & $\begin{array}{c}\mathrm{E}_{\mathrm{corr}} \\
(\mathrm{mV} / \mathrm{SCE})\end{array}$ & $\begin{array}{c}I_{\text {corr }} \\
\left(\mu \mathrm{A} / \mathrm{cm}^{2}\right)\end{array}$ & $-b_{c}(m V / d e c)$ & $\begin{array}{c}\mathrm{b}_{\mathrm{a}} \\
(\mathrm{mV} / \mathrm{dec})\end{array}$ & $\begin{array}{c}\mathrm{E} \\
(\%)\end{array}$ \\
\hline \multirow{4}{*}{ Blank } & 298 & -567 & 94 & 99 & 108 & --- \\
\hline & 308 & -544 & 157 & 126 & 68 & --- \\
\hline & 318 & -545 & 305 & 129 & 75 & -- \\
\hline & 328 & -537 & 399 & 136 & 78 & --- \\
\hline \multirow{4}{*}{$\mathrm{ACE}$} & 298 & -718 & 11 & 69 & 111 & 88.3 \\
\hline & 308 & -718 & 19 & 75 & 126 & 87.9 \\
\hline & 318 & -735 & 52 & 60 & 164 & 83.0 \\
\hline & 328 & -675 & 92 & 73 & 79 & 76.9 \\
\hline
\end{tabular}

It has been observed that the corrosion current density $\left(\mathrm{I}_{\text {corr }}\right)$ increased with the increase in ACE temperature. It is seen also that the argan press cake extract investigated has inhibiting properties at all temperatures studied and the values of inhibition efficiency decrease with temperature increase. We were interested in exploring the activation energy of the corrosion process and the thermodynamics of adsorption of ACE. This was accomplished by investigating the temperature dependence of the corrosion current, obtained using Tafel extrapolation method. The corrosion reaction can be regarded as an Arrhenius-type process; the rate is given by: 


$$
I_{\text {corr }}=A \exp \left(\frac{-E_{a}}{R T}\right)
$$

where $E a$ is the apparent activation corrosion energy, $T$ is the absolute temperature, $A$ is the Arrhenius pre-exponential constant and $R$ is the universal gas constant. This equation can be used to calculate the Ea values of the corrosion reaction without and with ACE. Plotting the natural logarithm of the corrosion current density versus $1 / \mathrm{T}$, the activation energy can be calculated from the slope. The temperature dependence of $\mathrm{C} 38$ steel dissolution in $1 \mathrm{M} \mathrm{HCl}$ and in the presence of the inhibitor is presented in Arrhenius co-ordinates in Fig. 7. The calculated values of the apparent activation corrosion energy in the absence and presence of ACE are listed in the Table 4. All the linear regression coefficients were close to one. The value of $\mathrm{E}_{\mathrm{a}}$ found for ACE is higher than that obtained for $1 \mathrm{M} \mathrm{HCl}$ solution. The increase in the apparent activation energy may be interpreted as physical adsorption that occurs in the first stage [40]. Szauer and Brand [41] explained that the increase in activation energy can be attributed to an appreciable decrease in the adsorption of the inhibitor on the C38 steel surface with increase in temperature. As adsorption decreases more desorption of the inhibitor molecules occurs because these two opposite processes are in equilibrium. Due to more desorption of inhibitor molecules at higher temperatures, an important surface of C38 steel comes in contact with aggressive environment, resulting increased corrosion rates with increase in temperature [41].

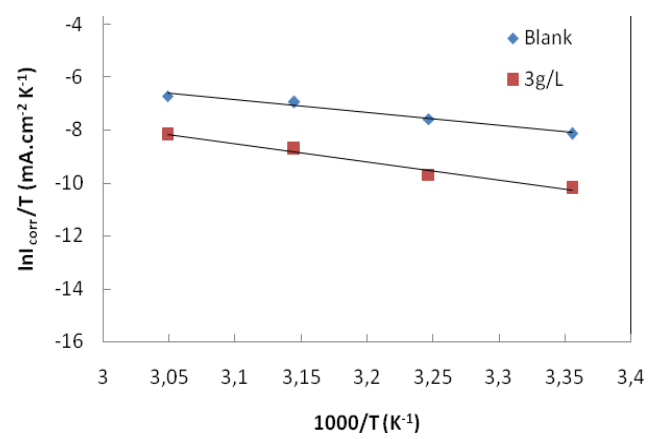

Figure 7. Relation between $\operatorname{Ln}\left(\mathrm{I}_{\text {corr }} / \mathrm{T}\right)$ and $1000 / \mathrm{T}$ at different temperatures.

An alternative formulation of Arrhenius equation is [42]:

$$
I_{\text {corr }}=\frac{R T}{N h} \exp \left(\frac{\Delta S_{a}^{*}}{R}\right) \exp \left(\frac{\Delta H_{a}^{*}}{R T}\right)
$$

where $h$ is Planck's constant, $N$ is Avogadro's number, $\Delta S_{a}^{*}$ is the entropy of activation and $\Delta H_{a}^{*}$ is the enthalpy of activation. Fig. 8 shows a plot of Ln $\left(\mathrm{I}_{\text {corr }} / \mathrm{T}\right)$ vs. 1/T. Straight lines are obtained with a slope of $\Delta H_{a}^{*} / R$ and an intercept of $\mathrm{Ln} \mathrm{R} / \mathrm{Nh}+\frac{\Delta S_{a}^{*}}{R}$ from which the values of $\Delta S_{a}^{*}$ and $\Delta H_{a}^{*}$ are calculated and are given in Table 4. Inspection of these data revealed that the thermodynamic parameters $\left(\Delta H_{a}^{*}\right.$ and $\left.\Delta S_{a}^{*}\right)$ for dissolution reaction of $\mathrm{C} 38$ steel in $1 \mathrm{M} \mathrm{HCl}$ in 
the presence of the inhibitor are higher than those obtained in the absence of the inhibitor. The positive sign of $\Delta H_{a}^{*}$ reflects the endothermic nature of the C38 steel dissolution process, suggesting that the dissolution of C38 steel is slow [43] in the presence of the inhibitor. On comparing the values of the entropy of activation $\Delta S_{a}^{*}$ given in Table 4 , it is clear that the entropy of activation decreases more negatively in the presence of argan press cake extract than in the absence of inhibitor, which reflects the formation of an ordered stable layer of the inhibitor on the steel surface [44].

Table 5. Values of activation parameters for mild steel in $1 \mathrm{M} \mathrm{HCl}$ in the absence and the presence of $3 \mathrm{~g} / \mathrm{L}$ of ACE.

\begin{tabular}{ccccc}
\hline Inhibitor & $\Delta H_{a}^{*}(\mathrm{~kJ} / \mathrm{mole})$ & $\Delta S_{\mathrm{a}}^{*}(\mathrm{~J} / \mathrm{mole})$ & $E_{a}(\mathrm{~kJ} / \mathrm{mol})$ & $E_{a}-\Delta H_{a}^{*}$ \\
\hline $1 \mathrm{M} \mathrm{HCl}$ & 38.4 & -75.9 & 41.0 & 2.6 \\
$\mathrm{ACE}$ & 57.3 & -90.6 & 59.9 & 2.6 \\
\hline
\end{tabular}

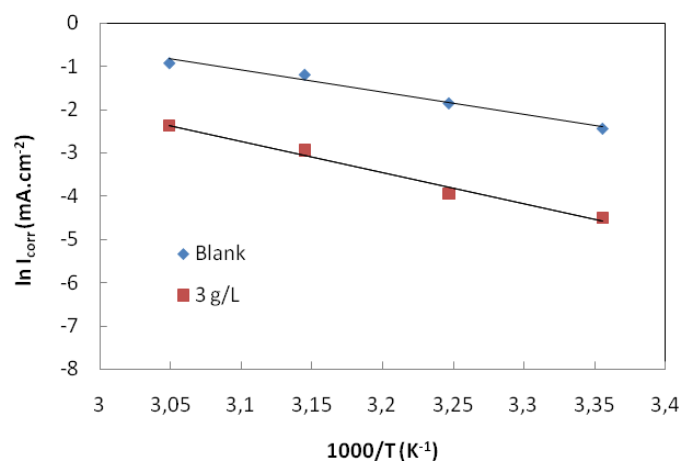

Figure 8. Arrhenius plots of steel in $1 \mathrm{M} \mathrm{HCl}$ with and without $3 \mathrm{~g} / \mathrm{L} \mathrm{ACE}$.

We remark that Ea and $\Delta H_{a}^{*}$ values vary in the same way (Table 5). This result permit to verify the known thermodynamic reaction between the Ea and $\Delta H_{a}^{*}$ as shown in Table 5 [45]:

$$
E_{a}-\Delta H_{a}^{*}=R T
$$

\section{Conclusion}

ACE examined acted as an efficient corrosion inhibitor in $1 \mathrm{M} \mathrm{HCl}$. Polarization studies showed that ACE was a mixed-type inhibitor with predominant cathodic effectiveness and its inhibition efficiency increased with the inhibitor concentration but decreases with rise in temperature. Impedance method indicates that ACE adsorbs on the C38 steel surface with increasing transfer resistance and decreasing of the double-layer capacitance. The adsorption of ACE on the $\mathrm{C} 38$ steel in $1 \mathrm{M} \mathrm{HCl}$ solution obeys Langmuir adsorption isotherm with high correlation coefficient. The adsorption process is a spontaneous and exothermic process. The inhibitor efficiencies determined by electrochemical 
polarisation, electrochemical impedance spectroscopy and gravimetric methods are in good agreement

\section{Acknowledgements}

The authors wish to thank the Volubilis program MA/10/226 for supporting this work. Prof. S.S. Deyab and Prof. B. Hammouti extend their appreciation to the Deanship of Scientific Research at King Saud University for funding the work through the research group project.

\section{References}

1. $\quad$ Ramesh S, Rajeswari S, Maruthamuthu S. Mater Lett. 2003;57:4547.

2. Zarrok H, Oudda H, Zarrouk A, Salghi R, Hammouti B, Bouachrine M. Der Pharm Chem. 2011;3:576.

3. Mihit M, Laarej K, Abou El Makarim H, Bazzi L, Salghi R, Hammouti B. Arab J Chem. 2010;3:55.

4. Mihit M, Bazzi L, Salghi R, Hammouti B, El Issami S, Ait Addi E. ISJAEE. 2008;62:173.

5. Barouni K, Bazzi L, Salghi R, Mihit M, Hammouti B, Albourine A, El Issami S. Mater Lett. 2008;62:3325.

6. El Issami S, Bazzi L, Mihit M, Hammouti B, Kertit S, Ait Addi E, Salghi R. Pig Res Tech. 2007;36:161.

7. Mihit M, Salghi R, El Issami S, Bazzi L, Hammouti B, Ait Addi E, Kertit S. Pig Res Tech. 2006;35:151.

8. Mihit M, El Issami S, Bouklah M, Bazzi L, Hammouti B, Ait Addi E, Salghi R, Kertit S. Appl Surf Sci. 2006;252:2389.

9. El Issami S, Bazzi L, Mihit M, Hilali M, Salghi R, Ait Addi El. J Phys IV. 2005;123:307.

10. El Issami S, Bazzi L, Hilali M, Salghi R, Kertit S. Ann Chim Sci Mat. 2002;27:63.

11. Salghi R, Bazzi L, Hammouti B, Kertit S. Bull Electrochem. 2000;16:272.

12. Hammouti B, Salghi R, Kertit S. J. Electrochem Soc India. 1998;47:31.

13. Afia L, Salghi R, Bazzi E, Zarrouk A, Hammouti B, Bouri M, Zarrouk H, Bazzi L, Bammou L. Res Chem Intermed. In press. DOI 10.1007/s11164012-0496-y (2012).

14. M El Ouariachi El, Paolini J, Bouyanzer A, Tomi P, Hammouti B, Salghi R, Majidi L, Costa J. J Med Plants Res. 2011;5:5773.

15 Chetouani A, Hammouti B. Bull Electrochem. 2004;20:343.

16 Bouyanzer A, Hammouti B, Majidi L, Haloui B. Port Electrochim Acta. 2010;28:165.

17. Bouklah M, Hammouti B. Port Electrochim Acta. 2006;24:457.

18. Emeka EO. Port Electrochim Acta. 2008;26:303.

19. Lebrini M, Robert F, Lecante A, Roos C. Corros Sci. 2011;53:687.

20. Olusegun AK, Oforka NC, Ebenso EE. J Corros Sci Eng. 2004;8:1.

21. Selles C, Benali O, Tabti B, Larabi L, Harek Y. J Mater Environ Sci. 2012;3(1):206-219. 
22. Riggs Jr OL., In: Nathan CC, editor. Corrosion Inhibitors. Houston, TX, USA: The National Association of Corrosion Engineers (NACE); 1973. p.2-27.

23. Lorentz WJ, Mansfeld F. Corros Sci. 1986;31:467.

24. Benali O, Larabi L, Tabti B, Harek Y. Anti-corr Meth Mater. 2005;52:280.

25. Bartos M, Hackerman N. J Electrochem Soc. 2000;139:3428.

26. Caprani A, Epelboin I, Morel P. In: Corros Inhibitors. Ferrara, Italy; 1975. p.571.

27. Bessone J, Mayer C, Tuttner K, Lorenz WJ. Electrochim. Acta. 1983;28:171.

28. Benali O, Larabi L, Mekelleche SM, Harek Y. J Mater Sci. 2006;41:7064.

29. Benali O, Larabi L, Harek Y. J Appl Electrochem. 2009;39:769.

30. Merah S, Larabi L, Benali O, Harek Y. Pig Res Tech. 2008;37(5):291.

31. Ma H, Chen S, Yin B, Zhao S, Liu X. Corros Sci. 2003;45:867.

32. Bentiss F, Traisnel M, Lagrenee M. Corros Sci. 2000;42:127.

33. Murlidharan S, Phani KLN, Pitchumani S, Ravichandran S. J Electrochem Soc. 1995;142:1478.

34. Abdel Rehim SS, Hazzazi OA, Amin MA, Khaled FK. Corros Sci. 2008;50:2258.

35. Ashassi Sorkhabi H, Seifzadeh D, Hosseini MG. Corros Sci. 2008;50:3363.

36. Emregul KC, Akay AA, Atakol O. Mater Chem Phys. 2005;93:325.

37. Sahin M, Bilgic S, Yilmaz H. Appl Surf Sci. 2002;195:1.

38. Bilgic S, Caliskan N. Appl Surf Sci. 1999;152:107.

39. Popova A, Sokolova E, Raicheva S, Christov M. Corros Sci. 2003;45:33.

40. Martinez S, Stern I. Appl Surf Sci. 2002;199:83.

41. Szauer T, Brand A. Electrochim Acta. 1981;26:1219.

42. Bochris J.O’M, Reddy AKN. Modern Electrochemistry. New York: Plenum Press; 1977. (vol 2)

43. Guan NM, Xueming L, Fei L. Mater Chem Phys. 2004;86:59.

44. Yurt A, Balaban A, Kandemir SU, Bereket G, Erk B. Mater Chem Phys. 2004;85:420.

45. Benali O, Larabi L, Traisnel M, Gengembre L, Harek Y. Appl Surf Sci. 2007;253:6130. 